\title{
HUBUNGAN PEMAHAMAN NAPZA DENGAN SIKAP TERHADAP PENYALAHGUNAAN NAPZA ( Studi Korelasi Pada Siswa Kelas VIII SMP Negeri Se-Kecamatan Johar Baru )
}

\author{
Nurbaiti Fadhillah ${ }^{1}$ \\ Dra. Endang Setyowati ${ }^{2}$ \\ Dr. Awaluddin Tjalla ${ }^{3}$
}

\begin{abstract}
Abstrak
Penelitian ini bertujuan untuk menganalisis ada atau tidaknya hubungan antara pemahaman tentang NAPZA dengan sikap penolakan penyalahgunaan NAPZA pada siswa kelas VIII SMP Negeri se-Kecamatan Johar Baru. Metode penelitian yang digunakan adalah penelitian korelasional dengan jenis kuantitatif. Penelitian dilaksanakan di 4 SMP Negeri Kecamatan Johar baru,Jakarta Pusat, dengan sampel 140 siswa. Sampel diambil dengan menggunakan sampling acak sederhana. Pengumpulan data dilakukan dengan menggunakan instrumen tes untuk mengukur variabel pemahaman tentang NAP$Z A$ dan menggunakan instrumen untuk mengukur variabel sikap penolakan penyalahgunaan NAPZA. Teknik analisis data yang digunakan adalah korelasi product moment pearson, uji koefisien korelasi dan dilanjutkan dengan uji-t pada taraf signifikan 5\%. Hasil pengujian hipotesis menunjukan bahwa rhitung $=0,472$ dengan taraf signifikansi 0,05, maka diperoleh $r$ tabel $=0,176$ ternyata $r$ hitung $>r$ tabel, jadi semua hipotesis nol ditolak. Dengan demikian hipotesis alternatif diterima. Artinya terdapat hubungan positif antara pemahaman tentang NAPZA dengan sikap penolakan penyalahgunaan NAPZA pada siswa kelas VIII SMP Negeri se-Kecamatan Johar Baru,Jakarta Pusat. Selanjutnya dilakukan uji-t dengan taraf signifikansi 5\% $(d k=n-2)$ dan diperoleh $t$ hitung $=3,14>t$ tabel $=1,65$ Hal ini menunjukan adanya hubungan yang signifikan antara pemahaman tentang NAPZA dengan sikap penolakan penyalahgunaan NAPZA pada siswa kelas VIII SMP Negeri se-Kecamatan Johar Baru, Jakarta Pusat. Implikasi dari hasil penelitian ini ditujukan kepada guru BK untuk dapat memberikan informasi mengenai NAPZA sebagai upaya pencegahan penyalahgunaan NAPZA berupa pemberian materi bimbingan klasikal dan pengadaan layanan bimbingan kelompok.
\end{abstract}

Kata Kunci : NAPZA, Pemahaman, Sikap

\footnotetext{
Mahasiswa Jurusan Bimbingan dan Konseling FIP UNJ, nurbaitifadhillah@gmail.com

Dosen Bimbingan dan Konseling FIP UNJ,

3 Dosen Bimbingan dan Konseling FIP UNJ, awaluddintjalla@yahoo.com
} 


\section{Pendahuluan}

Permasalahan NAPZA di Indonesia semakin mengkhawatirkan. Peredarannya bukan hanya berpusat di kota-kota besar saja, tapi sudah sampai kepada pelajar tingkat yang paling bawah. Korban penyalahgunaan NAPZA kini tidak hanya terbatas pada kalangan pelajar ekonomi menengah ke atas, tetapi sudah merambah kepada pelajar ekonomi menengah ke bawah, baik di perkotaan maupun di pedesaan. Penyalahgunaan NAPZA tidak hanya melibatkan pelajar SMP-SMA tetapi pelajar SD maupun TK pun sekarang sudah terkena 'virus mematikan' tersebut.

Dari hasil survei Penyalahgunaan dan Peredaran Gelap Narkoba (P4GN) BNN Republik Indonesia pada tahun 2009 menyatakan bahwa rata-rata usia pertama kali menyalahgunakan NAPZA pada usia yang sangat muda yaitu 12-15 tahun. Angka penyalahgunaan NAPZA berdasarkan tingkat pendidikan SLTP/SMP tahun 2012 berjumlah 9.743 kasus.Fakta ini mengindikasikan bahwa peredaran gelap NAPZA masih tetap marak di kalangan pelajar di Indonesia.

Berbekal pemahaman tentang NAPZA diharapkan para remaja khususnya siswa SMP mampu membentengi diri dari bahaya NAPZA. Berdasarkan hasil studi pendahuluan yang dilakukan peneliti dengan cara penyebaran angket, peneliti menemukan bahwa masih banyak siswa yang tidak memahami apa NAPZA, apa saja jenisnya dan bagaimana dampak dari penyalahgunaan NAPZA tersebut, namun ada juga siswa yang mengetahui tentang NAPZA, siswa mengetahui NAPZA itu obat-obatan yang berbahaya bagi kesehatan dan dilarang oleh pemerintah, namun siswa tidak mengetahui seberapa jauh dampak dari penyalahgunaan NAPZA, dan tidak mengetahui apa saja jenis-jenis NAPZA, dan ratarata dari mereka mengetahui informasi tersebut dari internet dan dari teman.

Pemahaman yang cukup baik akan mempengaruhi sikap siswa, sehingga siswa mempunyai sikap positif terhadap penyalahgunaan NAPZA, semakin baik pengetahuan tentang NAPZA semakin positif pula sikap terhadap penyalahgunaan NAPZA (kecenderungan untuk menghindari penyalahgunaan NAPZA), sedangkan pada remaja dengan pemahaman yang kurang akan mempunyai kecen- derungan ke arah yang negatif (kecenderungan untuk mendekati penyalahgunaan NAPZA).

Bedasarkan hal-hal tersebut di atas, maka rumusan masalah dalam penelitian ini adalah mengenai: "Apakah terdapat hubungan antara pemahaman NAPZA dengan sikap terhadap penyalahgunaan NAPZA pada siswa kelas VIII SMP Negeri se-Kecamatan Johar Baru?"

Tujuan mengadakan penelitian ini yaitu untuk menganalisis ada tidaknya hubungan antara pemahaman NAPZA dengan sikap terhadap penyalahgunaan NAPZA

\section{Kajian Teori \\ Hakikat Sikap}

Secara etimologis kata sikap adalah perbuatan yang berdasarkan pendirian atau pendapat atau keyakinan.

Secara historis, istilah "sikap" (attitude) digunakan pertama kali oleh Herbert Spencer yang pada saat itu diartikan olehnya sebagai status mental seseorang. Di masa-masa awal itu pula penggunaan konsep sikap sering dikaitkan dengan konsep mengenai postur fisik atau tubuh seseorang.

Selanjutnya menurut Gordon Allport sikap merupakan semacam kesiapan untuk bereaksi terhadap suatu objek dengan cara-cara tertentu. Kesiapan yang dimaksud merupakan kecenderungan potensial untuk bereaksi dengan cara tertentu apabila individu dihadapkan pada suatu stimulus yang menghendaki adanya respons.

Menurut Allport Struktur sikap dibagi menjadi 3 komponen yang saling menunjang. Ketiga komponen pembentukan sikap tersebut yaitu sebagai komponen kognitif, afektif dan konatif.

\section{1) Komponen Kognitif}

Komponen kognitif berisi kepercayaan seseorang mengenai apa yang berlaku atau apa yang benar bagi objek sikap.

\section{2) Komponen Afektif}

Komponen afektif menyangkut masalah emosional subyektif seseorang terhadap suatu objek sikap. Secara umum, komponen ini disamakan dengan perasaan yang dimiliki terhadap sesuatu.

3) Komponen Konatif

Komponen ini menunjukkan bagaimana kecen- 
derungan berprilaku yang ada dalam diri seseorang yang berkaitan dengan objek sikap yang dihadapinya

\section{Hakikat Pemahaman}

Secara etimologis, pemahaman berasal dari kata paham yang berarti pandai dan mengerti benar. Sedangkan pemahaman memiliki pengertian yaitu suatu kemampuan untuk mengetahui dan mengerti secara mendalam, merupakan proses berpikir yang diperlukan manusia dalam kehidupan sehari-hari.

Menurut Benjamin Samuel Bloom seorang ahli pendidikan memahami (understand) adalah mengkonstruk makna atau pengertian berdasarkan pengetahuan awal yang dimiliki siswa, atau mengintregasikan pengetahuan yang baru ke dalam skema yang telah ada di dalam pemikiran siswa. Karena penyusunan skema adalah konsep, maka pengetahuan konseptual merupakan dasar pemahaman.

Benjamin Samuel Bloom mengemukakan konsep taksonomi belajar, mengelompokan tujuan belajar berdasarkan domain atau kawasan belajar yaitu kawasan kognitif, kawasan afektif dan kawasan psikomotor. Kategori memahami mencakup tujuh proses kognitif yaitu: menafsirkan (interpreting), memberikan contoh (examplifying), mengklasifikasikan (classifying), meringkas (summarizasing), menarik interferensi (inferring), membandingkan (comparing), dan menjelaskan (explaning).

\section{Hakikat NAPZA}

NAPZA adalah obat/bahan/zat, yang bukan tergolong makanan. Jika diminum, diisap, dihirup, ditelan atau disuntikan, berpengaruh terutama pada kerja otak (susunan saraf pusat), dan sering menyebabkan ketergantungan. Akibatnya, kerja otak berubah (meningkat atau menurun). Demikian pula fungsi vital organ tubuh lain (jantung, peredaran darah, pernapasan, dan lain-lain).

NAPZA (Narkotika, Psikotropika,dan Zat adiktif lainnya) adalah istilah dalam dunia kedokteran. Disini penekanannya pada pengaruh ketergantungannya. Oleh karena itu, selain narkotika dan psikotropika, yang termasuk NAPZA adalah juga obat, bahan atau zat, yang tidak diatur dalam undang-undang, tetapi menimbulkan ketergantungan, dan sering disalahgunakan.

\section{Metode Penelitian}

Penelitian dilakukan kepada siswa kelas VIII SMP Negeri se-kecamatan Johar Baru. Penelitian dilaksanakan pada bulan Maret-Desember 2014 tahun ajaran 2013-2014. Adapun subyek dalam penelitian ini melibatkan 4 sekolah dengan jumlah total 140 siswa.. Teknik sampling yang digunakan yaitu teknik acak sederhana (simple random sampling).

Metode yang digunakan dalam penelitian ini adalah metode korelasional, yakni melihat bentuk hubungan antara variabel bebas yaitu pemahaman NAPZA (variabel $X$ ) dan variabel terikat yaitu sikap terhadap penyalahgunaan NAPZA (variabel Y). Metode korelasional adalahmetode penelitian yang digunakan untuk menemukan ada tidaknya hubungan dan apabila ada, berapa eratnya hubungan serta berarti atau tidak hubungan itu. Metode penelitian ini diharapkan dapat menemukan hubungan antara variabel-variabel yang diteliti.

Teknik analisis data yang digunakan adalah uji persyaratan analisis menggunakan Product Moment dari Pearson. Sebelum melakukan analisa data maka terlebih dahulu dilakukan uji normalitas data. Hipotesis dalam penelitian ini akan diuji dengan menggunakan teknik statistik: hipotesis nol, yang menunjukkan tidak adanya hubungan positif (lebih kecil dari nol) antara pengetahuan mengenai pemahaman NAPZA dengan sikap terhadap penyalahgunaan NAPZA. Hipotesis alternatifnya menunjukkan ada hubungan positif (sama dengan nol atau mungkin lebih besar dari nol) antara pemahaman NAPZA dengan sikap terhadap penyalahgunaan NAPZA.

\section{Hasil dan Pembahasan}

Data dalam penelitian ini diperoleh melalui penyebaran instrumen kepada 140 siswa di SMP Negeri se-Kecamatan Johar Baru. Hasil penghitungan instrumen tes pemahaman NAPZA yang terdiri dari 30 butir soal, memperoleh skor maksimum 30 dan skor minimum 11. Variabel pemahaman NAPZA terdiri dari soal-soal yang mencakup pengertian NAPZA, Jenis-jenis NAPZA, dampak penyalahgunaan NAPZA, upaya Pencegahan NAPZA dan UUD terkait NAPZA. 
Penghitungan menggunakan SPSS 17 diperoleh Mean sebesar 22 (dibulatkan) dan Standar Deviasi sebesar 3 (dibulatkan). Bila diinginkan penggolongan subjek ke dalam tiga kategori diagnosis pemahaman NAPZA, dari 140 responden terdapat 11 responden dengan presentase $7,86 \%$, yaitu responden yang memiliki pemahaman NAPZA tinggi, responden yang memiliki pemahaman NAPZA dengan kategori sedang sebanyak 114 responden dengan presentase $81,43 \%$ dan responden yang memiliki pemahaman NAPZA pada kategori rendah sebanyak 15 responden dengan persentase $10,71 \%$.Yang memiliki pengetahuan tinggi.

Tabel 1

Kategorisasi Variabel Pemahaman NAPZA

\begin{tabular}{|c|c|c|c|}
\hline Kategori & Skor & Frekuensi & Persentase (\%) \\
\hline Tinggi & $\geq 25$ & 11 & $7,86 \%$ \\
\hline Sedang & $19-25$ & 114 & $81,43 \%$ \\
\hline Rendah & $<19$ & 15 & $10,71 \%$ \\
\hline Total & & $\mathbf{1 4 0}$ & $\mathbf{1 0 0} \%$ \\
\hline
\end{tabular}

Melihat hasil analisa data pada variabel pemahaman NAPZA menunjukkan 11 siswa dengan presentase $7,86 \%$ memiliki pemahaman NAPZA yang tinggi, 114 siswa dengan presentase 81,43\% siswa memiliki pemahaman NAPZA sedang, dan kemudian 15 siswa dengan presentase $10,71 \%$ siswi yang memiliki pemahaman tentang NAPZA rendah. Sedangkan pada variabel sikap terhadap penyalahgunaan NAPZA terdapat 19 siswa dengan presentase $13,57 \%$ dengan kategori tinggi, 100 siswa dengan presentase $71,43 \%$ termasuk dalam kategori sedang, dan 21 siswa dengan presentase $15 \%$ termasuk kedalam kategori rendah.

Siswa SMP kelas VIII Negeri di Kecamatan Johar Baru yang termasuk dalam kategori tinggi pada variabel ini sebanyak 11 siswa, mereka adalah yang dapat menjawab dengan tepat 26 soal atau seluruhnya dari 30 butir soal. Siswa yang termasuk kedalam kategori tinggi yaitu 2 siswa berasal dari SMPN 2, 4 siswa dari SMPN 28, dan 5 siswa berasal dari SMPN 156.

Selanjutnya, siswa SMP Negeri di Kecamatan Johar Baru yang termasuk dalam kategori sedang pada variabel pemahaman NAPZA sebanyak 114 orang, mereka adalah yang dapat menjawab dengan tepat 19 soal hingga 25 soal dari 30 butir soal. Siswa SMP Negeri di Kecamatan Johar Baru yang termasuk dalam kategori sedang terdiri dari 28 siswa berasal dari SMPN 28, 28 dari SMPN 156, 29 siswa berasal dari SMPN 2, dan 29 siswa berasal dari SMPN 76 Jakarta.

Kemudian, siswa kelas VIII SMP Negeri di Kecamatan Johar Baru yang termasuk dalam kategori rendah pada variabel pemahaman NAPZA sebanyak 15 orang, mereka adalah yang dapat menjawab dengan tepat 11 soal hingga 18 soal dari 30 butir soal. Siswa kelas VIII SMP Negeri di Kecamatan Johar Baru termasuk dalam kategori rendah terdiri dari 7 siswa berasal dari SMPN 76, 3 siswa dari SMP 28, 2 siswa dari SMP 156 dan 3 siswa berasal dari SMPN 2 Jakarta.

Hasil penghitungan instrumen angket sikap terhadap penyalahgunaan NAPZA yang terdiri dari 30 pertanyaan, memperoleh skor maksimum 120 dan skor minimum 90.

Penghitungan menggunakan SPSS 17 diperoleh Mean sebesar 111 (dibulatkan) dan Standar Deviasi sebesar 7 (dibulatkan). Bila diinginkan penggolongan subjek ke dalam tiga kategori diagnosis sikap terhadap penyalahgunaan NAPZA dilihat dari 140 responden terdapat 19 responden dengan presentase $13,57 \%$, yaitu responden yang memiliki sikap terhadap penyalahgunaan NAPZA tinggi, responden yang sikap penyalahgunaan NAPZA dengan kategori sedang sebanyak 100 responden dengan persentase $71,43 \%$, dan responden yang memiliki sikap terhadap penyalahgunaan NAPZA dengan kategori rendah sebanyak 21 responden dengan persentase 15\%.

Tabel 2

Kategorisasi Variabel Sikap Terhadap Penyalahgunaan NAPZA

\begin{tabular}{|c|c|c|c|}
\hline Kategori & Skor & Frekuensi & Persentase (\%) \\
\hline Tinggi & $\geq 118$ & 19 & $13,57 \%$ \\
\hline Sedang & $104-118$ & 100 & $71,43 \%$ \\
\hline Rendah & $<104$ & 21 & $15,00 \%$ \\
\hline Total & & $\mathbf{1 4 0}$ & $\mathbf{1 0 0 \%}$ \\
\hline
\end{tabular}

Berdasarkan analisis hasil angket pada variabel sikap terhadap penyalahgunaan NAPZA, bah- 
wa siswa yang memiliki pemahaman NAPZA yang tinggi dan diikuti dengan sikap terhadap penolakan penyalahgunaan NAPZA yang tinggi adalah siswa yang memiliki kecendrungan untuk tidak menggunakan NAPZA atau menolak untuk menyalahgunakan NAPZA.

Pemahaman NAPZA pada kategorisasi sedang dan diikuti dengan sikap penyalahgunaan NAPZA yang sedang memiliki presentase terbanyak pada hasil penelitian ini. Artinya siswa masih perlu memahami secara mendalam tentang NAPZA agar memiliki sikap penolakan penyalahgunaan NAPZA.

Kemudian siswa yang memiliki pemahaman NAPZA yang rendah dan diikuti dengan sikap penolakan terhadap penyalahgunaan NAPZA yang rendah yang berarti siswa tidak mengetahui dan mengerti apa yang dimaksud dengan NAPZA dan siswa ini juga memiliki kecendrungan untuk menyalahgunakan NAPZA.

Hasil penghitungan kedua variabel, yakni variabel pemahaman NAPZA dan variabel sikap terhadap penyalahgunaan NAPZA, diuji normalitasnya dengan menggunakan uji kolmogrovsmirnov. Data dikatakan normal jika nilai residual yang terdistribusi secara normal memiliki probabilitas signifikan lebih dari 0,05. Hasil uji normalitas menunjukkan nilai signifikansi untuk variabel pemahaman NAPZA sebesar 0,113 dan variabel sikap terhadap penyalahgunaan NAPZA sebesar 0,058 sehingga dapat disimpulkan bahwa kedua variabel berdistribusi normal dikarenakan nilai signifikansi lebih besar dari 0,05 .

Pengujian hipotesis antara kedua variabel menggunakan korelasi product moment, yakni merupakan uji statistik non parametrik yang digunakan dalam analisis data pada penelitian ini. Berdasarkan hasil penghitungan uji hipotesis, dapat diketahui koefisien korelasi/rhitungsebesar 0,472, hal ini berarti hasil koefisien rhitung> rtabel 0,176 (angka yang telah ditentukan berdasarkan jumlah responden yaitu 140), maka hipotesis nol (Ho) ditolak. Pengujian hipotesis dapat pula dilakukan dengan membandingkan taraf signifikansi. Taraf signifikansi hitung antara pemahaman NAPZA dengan sikap terhadap penyalahgunaan NAPZA sebesar 0,015 . Oleh karena taraf signifikansi hitung yang didapat lebih kecil dari 0,05 (taraf signifikansi yang telah diten- tukan), maka hipotesis nol (Ho)ditolak. Jadi pada penelitian ini hipotesis yang diterima adalah hipotesis alternatif $(\mathrm{Ha})$.

Berdasarkan pemaparan yang telah dijelaskan, dapat disimpulkan bahwa terdapat hubungan positif antara pemahaman NAPZA dengan sikap terhadap penyalahgunaan NAPZA pada siswa kelas VIII SMP Negeri se-kecamatan Johar Baru. Kemudian siswa yang memiliki pemahaman NAPZA yang rendah dan diikuti dengan sikap penolakan terhadap penyalahgunaan NAPZA yang rendah yang berarti siswa tidak mengetahui dan mengerti apa yang dimaksud dengan NAPZA dan siswa ini juga memiliki kecendrungan untuk menyalahgunakan NAPZA. Karena ada beberapa faktor yang mempengaruhi pembentukan sikap seseorang, diantaranya pengalaman pribadi, pengaruh oranglain yang dianggap penting, pengaruh kebudayaan, pengaruh media massa, intitusi atau lembaga pendidikan dan lembaga agama, serta faktor emosi dalam diri individu. Pengetahuan yang rendah tentang NAPZA dapat mempengaruhi sikap siswa terhadap penyalahgunaan NAPZA. Dalam hal ini diperlukan peran aktif beberapa pihak yang dapat membantu upaya pencegahan penyalahgunaan NAPZA seperti pihak sekolah, orangtua, masyarakat, BNN dan pemerintah untuk dapat memberikan informasi tentang NAPZA kepada siswa agar siswa dapat membentengi diri untuk tidak meyalahgunakan NAPZA. Selain itu dalam komponen pembentukan sikap siswa ini secara kognitif tidak mempercayai dampak dan bahaya penyalahgunaan NAPZA dan memiliki emosional yang tidak stabil sehingga siswa menunjukan kecendrungan berprilaku untuk menyalahgunakan NAPZA.

\section{Simpulan dan Saran}

Penelitian yang telah dilakukan memberikan kesimpulan bahwa terdapat Berdasarkan pemaparan yang telah dijelaskan, dapat disimpulkan bahwa ada hubungan antara pemahaman NAPZA dengan sikap terhadap penyalahgunaan NAPZA. Tetapi sikap tidak sepenuhnya dipengaruhi oleh pemahaman siswa tentang NAPZA, melainkan dipengaruhi pula oleh beberapa faktor seperti faktor lingkungan dan faktor NAPZA itu sendiri. Oleh karena fokus penelitian ini hanya pada faktor pemahaman sebagai salah satu faktor yang mempengaruhi sikap, maka analisis 
pembahasan dalam penelitian ini hanya terkait pada faktor pemahaman.

Adapun saran-saran yang dibuat untuk penelitian lanjutan adalah sebagai berikut:

1. Universitas yang memiliki jurusan BK mengevaluasi rancangan strategi pembelajaran terkait layanan konseling, sehingga calon guru BK dapat menguasai landasan teoretis dan mengaplikasikannya dengan lebih baik.

2. Guru BK melakukan upaya-upaya guna meningkatkan pemahaman tentang NAPZA kepada siswa guna mencegah penyalahgunaan NAPZA.

3. Peneliti lanjutan yang tertarik dengan pembahasan serupa disarankan untuk meneliti mengenai upaya yang dapat dilakukan untuk meningkatkan pemahaman tentang NAPZA ataupun upaya meningkatkan sikap penolakan penyalahgunaan NAPZA.

\section{Daftar Pustaka}

Anderson,L.W,\& Krathwohl (Eds). (2001). A Taxonomy for Learning, Teaching, and Assessing: A Revision of Bloom's Taxonomy of Educational Objectives. New York: Longman.

Arikunto Suharsimi. 2010. Prosedur Penelitian Suatu pendekatan Praktik, Jakarta : Rineka Cipta

Azwar Saifudin. 2013. Sikap Manusia: Teori dan Pengukurannya. Edisi II. Cetakan XVIII. Yogyakarta: Pustaka Pelajar

BNN RI. 2004. Pedoman Pencegahan Penyalahgunaan Narkoba Bagi Pemuda. Jakarta: Badan Narkotika Nasional.

BNN RI. 2010. Petunjuk Teknis Advokasi Bidang Pencegahan Penyalahgunaan Narkoba Bagi Lembaga/Instansi. Jakarta : Direktorat Advokasi Deputi Bidang Pencegahan Badan Narkotika Nasional.

BNN RI. 2013. Jurnal Data Pencegahan dan Pemberantasan Penyalahgunaan dan Peredaran Gelap Narkoba(P4GN).Jakarta: Pusat Penelitian dan Informasi Badan Narkotika Nasional. 